\title{
A Framework for Learning Programming Using TQM
}

\author{
A. Yacob, M. Y. Mohd Saman, and M. H. Yusoff
}

\begin{abstract}
Computer programming is known for its complexity and difficulty among novice. Developing good computer programming skills requires students to do a lot of exercises. Besides, high self motivation is the only types of person that required in performing better in programming development. In this research, an exploration for PDCA cycle from manufacturing area will be transform into computer programming learning for continuous process improvements. Expected results from this study will reflect to the research questions. This paper contributed on the motivations of applying TQM to the programming learning using Problem-based learning through web-based environment. Therefore, we believe that constructive development through PBL and web-based programming learning tends to support cognitive development among novice.
\end{abstract}

Index Terms-Kaizen, PDCA, programming learning, TQM.

\section{INTRODUCTION}

As we move into the 21 st century, TQM (Total Quality Management) has been developed in many countries in a holistic framework. It aims to help organizations achieve performance excellence, particularly in customer and business results. Continuous improvement is one of the core values of TQM and can amount collectively to considerable gains in quality and reduction of costs [1]. The plan-do-check-action (PDCA) is a simple adaption used to help implement Kaizen concept [2].

People can take advantages of applying PDCA cycles in their application including computer programming learning. Implement and maintain the continuous improvement of educational quality in higher education institutions are very reasonable and at the same time challenging [3]. According to [4], innovation is the key to success in every sphere of life. Changes are happening in everyday life and one has to adapt to new situations and face challenges.

This work is organized as follow: Introduction in Section 1. Section 2 sheds some light on the Literature Review, including Learning Programming, TQM and Motivation. Section 3 will discuss about Research Methodology, section 4 about Learning Programming Framework using TQM. Finally, Conclusion and Future Work will be presented in Section 5.

Manuscript received August 16, 2012; revised October 30, 2012. This work was supported from University Malaysia Terengganu.

A. Yacob is with the Faculty Computer, Madia \& Technology.

M. H. Yusoff is with Department of Computer Science, UMT, 21030, Kuala Terengganu, Terengganu (e-mail: hafiz.yusoff@umt.edu.my).

\section{LITERATURE REVIEW}

Education is a continuous process of converting information into knowledge that can help students develop and explore further information. The problems and challenges faced by current educational systems suggest improving the teaching and learning process to suit current needs of industry and society [4].

\section{A. Learning Programming}

Learning styles in higher education has received increasing attention and plays a role in classroom performance. Besides, the culture factor also has an impact on the learning style scales. Several studies have shown that academic performance of university students is related to their learning styles. Teaching and learning programming are a complex and difficult set of activities.

There are different approaches to improve programming learning. Each of those tools has its own benefits and is difficult to find one suitable for all students needs. Depending on the actual knowledge level and preferable study method of each student, we need to make the right tool available at the right time. As stated by [9], blog is also an alternative used in programming learning. These tools used an internet as a media to make an online discussion and will be very helpful for educators.

Previous research [5] shows that visual programming can be more efficient than classical textual programming. By this way, students can be more motivated, less bored and not burden with the syntax of programming languages. Pseudo-code and flowchart have been widely use to explain programming solution [6]. Many different approaches have been suggested for programming teaching: Scratch System, collaborative work, simulation, games, teamwork skill, graphical programming, learning by doing approach and many more.

Technology also plays an important role to improve learning process. Scribbler robot and Alice used to allow students to interact with the fast world of programming through the use of instructions and programming structures represented by icons. In the context of this problem, it has been the need to implement more attractive methods in the teaching of programming [7]. These new strategies in the teaching of computer courses, is a fundamental pillar in the education of future engineers.

\section{B. Total Quality Management}

According to [3], continuous improvement is one of the core values of TQM. This approach is built around the premise that every step of the process, service and operation has room for improvement. TQM was not necessarily an outcome measure, but seeks to satisfy customer needs continuously. TQM follows both top-down and bottom up 
approach where the improvement is suggested by top management and workers of the organization. As stated by [10], the TQM principles can be grouped into Customer Focus, Leadership, Teamwork, Continuous Improvement, Measurement and Benchmarking.

\section{Kaizen}

Kaizen is the Japanese term and is a subset of TQM. It refers to a philosophy that focuses on continuous improvement. Kaizen was first implemented in several Japanese businesses after World War II. It has spread throughout the world and currently being implemented in other places other than business and productivity It assumes that every aspect of our life deserves to be constantly improved. According to [11], an important contribution to continuous process improvement is the kaizen. Kaizen are to prepare a work standard and continue to improve processes. It can be done by correcting the differences between the standard and actual results [12]. Kaizen takes the view that every process can be improved. Kaizen defines management's role in continuously encouraging and implementing small improvements. Everyone is encouraged to come up with small improvement suggestions on a regular basis. Improvement begins with the belief that every organization has opportunities for change and improves. Kaizen focuses on simplification by breaking down complex process into their sub-processes and then improving them.

\section{PDCA Cycles}

PDCA is the basic procedure of TQM and acronym for Plan, Do, Check and Actions. It was developed by W. Shewhart in the 1930's and also known as the Deming cycle. PDCA is a classic quality management model promoted and practiced in Japan by Dr. W. Edwards Deming[13]. It is an essential meaning for plan firstly, implementing the plan, checking the implementations and processing the results. The PDCA Cycle is a conceptual model for the adjustment of systematized processes improvement. It is the scientific summarization to the continuous and spiral improvement. The improved PDCA theory has been widely used in the enterprise quality management. It also becomes a logical work processes that allow activities effectively [14]. Under the perspective of TQM, the PDCA cycle should be used to drive the processes management. Detail about the PDCA cycle is briefly explained below:

1) Plan: Defining the concept, aims and objectives; identifying problems and critical points; training; developing templates, models, methodology.

2) Do: Do means implementing the planned processes, taking small steps in controlled circumstances.

3) Check: Measuring the results; evaluating the model; comparing the results with the established goals; preparing standards, quality assurance procedures, and the review process.

4) Act: After the check step, actions have to be taken to reach the necessary improvement based on what was studied in the previous step, implementation as a standard; introduction to the company culture.

\section{Motivation}

Motivation in learning has been widely discuss. Learning and motivation are highly complex facets of human behavior.
As stated by [15], the relation between attitude and motivation for learning has been actively studied in psychology. [16] found that attitude of students toward learning were correlate to achievement, motivation to learn, and self-regulated learning. Meanwhile, [17] studied on the relationship between teaching material and motivation for art's students. Regarding to [18], learning motivation may come from intrinsic (Individual attitude and expectation; and challenging goals) and extrinsic factors (clear direction; reward and recognition; punishment; and social pressure and competition.

\section{ReSEARCh Methodology}

\section{A. Questionnaire Design}

This research deploys a survey method in investigating the motivation level of the students toward programming learning. Motivation testing will be conducted to the number of sample students who are involved to test their motivation level. A questionnaire has been designed which is adapted from the Instructional Material Motivation Survey (IMMS) developed by John Keller [10]. To get the best results in this survey, the questionnaire was reviewed using a pilot study. Five Likert scale questions (1=strongly disagree, 5=strongly agree) used to represent student's assessment using pre-testing and post-testing for desired methodology.

\section{B. Data Collection and Validation}

A set of questionnaire will be distributed to obtain the demographic profile and examine about programming background, respondents' perception toward this subject, motivation and analysis for the testing. Testing over the programming skills of students involved will be collected and analyzed for comparison. Mathematical and statistical approach using SPSS 18.0 (Statistical Package for the Social Sciences) and SEM (structural equation modeling) will be used for the purpose of verification and data analysis. SEM was chosen as it is the most appropriate technique for modeling hierarchical latent constructs and is effective in removing the biasing effects of measurement error.

\section{Interview Session}

Interview sessions will be implemented among students to find out the reasons for the motivations.

\section{LEARNING PRogramming Framework UsING TQM}

In this paper, an effort to develop tools specifically designed for the needs of beginning programmers come arise[19]. This variety tools are important to motivate people by reduces teacher workload. According to [8], it is almost impossible for teachers to perform lecture due to big class sizes Previous research from [20] to improve student interest in software engineering learning using game development framework faced with some limitations. It including that approach available in lab and not at classroom, took a lot of time getting know C\#, need more technical support and too little on software architecture (too much on C\#, XNA and games). 
TABLE I: TQM IMPLEMENTATIONS

\begin{tabular}{|c|c|c|}
\hline Reff & Field & Description \\
\hline \multirow[b]{2}{*}[21]{} & \multirow{2}{*}{$\begin{array}{l}\text { Automotive } \\
\text { Industry }\end{array}$} & Ergonomics and kaizen. \\
\hline & & $\begin{array}{l}\text { Levels of absenteeism and accidents } \\
\text { reduced. }\end{array}$ \\
\hline \multirow{2}{*}{ [12] } & \multirow{2}{*}{$\begin{array}{l}\text { Software } \\
\text { Product }\end{array}$} & Kaizen. \\
\hline & & Provides a standard for core asset. \\
\hline \multirow[b]{2}{*}{ [13] } & \multirow{2}{*}{$\begin{array}{l}\text { Software } \\
\text { Quality }\end{array}$} & PDCA \\
\hline & & $\begin{array}{l}\text { Number of software defects and percentage } \\
\text { of requirement problems reduced. }\end{array}$ \\
\hline \multirow{2}{*}{ [22] } & \multirow{2}{*}{$\begin{array}{c}\text { Process } \\
\text { Reengineering }\end{array}$} & Kaizen, Automation (Promodel) \\
\hline & & Improvement in labor productivity. \\
\hline \multirow{2}{*}{ [23] } & \multirow{2}{*}{$\begin{array}{l}\text { Biochemical } \\
\text { Engineering }\end{array}$} & Kaizen \\
\hline & & Process lead times reduce (deliveries) \\
\hline \multirow[b]{2}{*}{ [24] } & \multirow{2}{*}{$\begin{array}{l}\text { Spanish local } \\
\text { Governments }\end{array}$} & Lean-kaizen. \\
\hline & & $\begin{array}{l}\text { Improved the processes and quality of } \\
\text { public services provided by the councils. }\end{array}$ \\
\hline \multirow[b]{2}{*}{ [25] } & \multirow{2}{*}{$\begin{array}{l}\text { Human } \\
\text { Resource }\end{array}$} & Lean-kaizen. \\
\hline & & $\begin{array}{l}\text { Improve cycle times in the human resource } \\
\text { selection and hiring process }\end{array}$ \\
\hline \multirow[b]{2}{*}{ [26] } & \multirow[b]{2}{*}{$\begin{array}{l}\text { Medical Process } \\
\text { Management }\end{array}$} & PDCA \\
\hline & & $\begin{array}{l}\text { Monitor the whole medical process and } \\
\text { improve the quality of medical services. }\end{array}$ \\
\hline \multirow[b]{2}{*}[3]{} & \multirow{2}{*}{$\begin{array}{l}\text { Higher } \\
\text { Education }\end{array}$} & PDCA, Self assessment \\
\hline & & $\begin{array}{l}\text { For strategic and continual improvement of } \\
\text { performance. }\end{array}$ \\
\hline \multirow[b]{2}{*}{ [27] } & \multirow{2}{*}{$\begin{array}{l}\text { Performance } \\
\text { Management } \\
\text { System }\end{array}$} & PDCA \\
\hline & & $\begin{array}{l}\text { Understanding for whole process and } \\
\text { manage performance better. }\end{array}$ \\
\hline \multirow{2}{*}{ [28] } & \multirow{2}{*}{$\begin{array}{l}\text { Software } \\
\text { Testing }\end{array}$} & $\begin{array}{l}\text { PDCA, Knowledge Management, Agile } \\
\text { Process, Benchmarking, GQM approach. }\end{array}$ \\
\hline & & $\begin{array}{l}\text { Promote the software testing process, } \\
\text { improve the testing service quality. }\end{array}$ \\
\hline \multirow[b]{2}{*}{ [29] } & \multirow[b]{2}{*}{$\begin{array}{l}\text { E-Learning } \\
\text { Project }\end{array}$} & PDCA \\
\hline & & $\begin{array}{l}\text { Better quality of Distance learning } \\
\text { education (Moodle platform) }\end{array}$ \\
\hline \multirow[b]{2}{*}{ [30] } & \multirow[b]{2}{*}{$\begin{array}{l}\text { Graphic } \\
\text { Interface }\end{array}$} & PDCA cycle and QC Story method. \\
\hline & & $\begin{array}{l}\text { Present an experimental study that } \\
\text { evaluates the usability and efficiency of a } \\
\text { framework for the generation of graphic } \\
\text { interfaces. }\end{array}$ \\
\hline \multirow[b]{2}{*}{ [31] } & \multirow[b]{2}{*}{ Medical } & PDCA \\
\hline & & $\begin{array}{l}\text { Improvement in documentation of pain } \\
\text { reassessments }\end{array}$ \\
\hline \multirow[b]{2}{*}{ [32] } & \multirow[b]{2}{*}{$\begin{array}{l}\text { Higher } \\
\text { Education }\end{array}$} & Lean Six Sigma \\
\hline & & $\begin{array}{l}\text { Become more responsive and offer better } \\
\text { service to students (real time application } \\
\text { acceptance, registration) }\end{array}$ \\
\hline [33] & Education & PDCA \\
\hline & & $\begin{array}{l}\text { Aiming to prepare students for statistical } \\
\text { problem solving with confident (text book) }\end{array}$ \\
\hline [34] & Higher & PDCA, mastery learning approach \\
\hline & Education & $\begin{array}{l}\text { Divides a subject matter or a course into } \\
\text { units that have predetermined objectives. }\end{array}$ \\
\hline
\end{tabular}

Refer to Table I above for the implementations of TQM in different fields for many different purposes and were proved for some benefits and advantages. As stated by [35], even visual programming language using Scratch is a good example for introductory programming [5][36], but it doesn't present the user with the source code from the flowchart generated. Versatile, simple and motivating potential makes LEGO kits a powerful help in a variety of learning scenarios. According to [37], students sometimes have certain difficulties to reinforce those basic concepts and also cannot focus the entire course contents because of didactic approach. Previous research [38][39] found several factors that often present challenges to collocated pair programming are limited facilities, geographic separation, and scheduling. Also, it was found that three reasons for difficulties of first year programming students are lack of experience in problem solving skills, difficult to imagine abstract terms in programming and difficult to turn the pseudo-code into a syntactically correct computer program [40]. [8] Mentioned that contribution to minimize some of limitation from the class size and students heterogeneity in knowledge and pace should be taken by using suitable tools.

Nowadays, TQM methodologies have been used in many different fields like automotive industry, software, medical, management and education. According to [41], the phrase 'change for the better' will results to the improvement. It could be related to the customer's satisfactions and advantages such as innovation, ease of use, on-time delivery, durability and low cost. Kaizen manage to reduce waste in areas such as inventory, waiting times, transportation, worker motion, employee skills, over production, excess quality and in processes. Kaizen also improves space utilization, product quality, use of capital, communications, production capacity and employee retention.

Previous researches have proved that TQM was successfully implemented in various fields. TQM benefits are including improves business, enhancing customer's satisfaction, reduce or eliminate problems, improved attitudes, enhanced communication, reduce waste and rework, improved customer/supplier relationships and for market competitiveness. Research from [42], was found that there are a significant relationship between the TQM implementation and the students' satisfaction of academic performance. It was suggested that TQM should be effectively implemented in the institutions of higher education.

\section{A. Web-Based Programming Learning}

Based on limitations that faced during computer programming learning, this research attempts to propose a conceptual framework for learning programming using TQM. An exhaustive literature review is carried out to understand the conceptual development of TQM, to highlight the importance of various contributors that lead to effective implementation of TQM. Figure 1 below show the proposed framework for learning programming using TQM

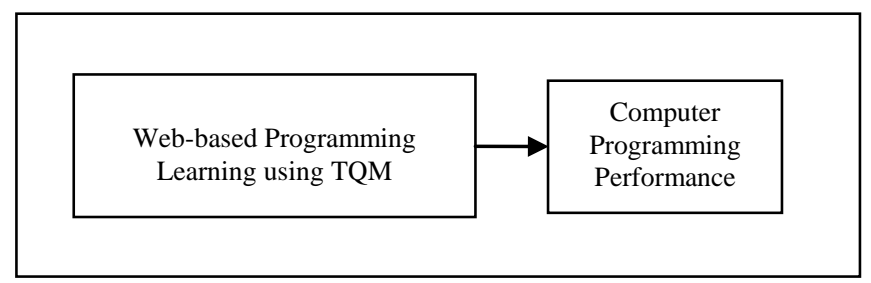

Fig. 1. Framework for learning programming.

Research Question:

Is there any significant difference in term of students' motivation after learning using 'TQM approach websites' compared to conventional approach?

$H_{0}$ : There is no significant difference in term of students' motivation after learning using 'TQM approach websites' compared to conventional approach. 
$H_{1}$ : $\quad$ There is a significant difference in term of students motivation after learning using 'TQM approach websites' compared to conventional approach.

TABLE II: PROBLEM GIVEN IN LEARNING PROGRAMMING

\begin{tabular}{|c|c|}
\hline \multicolumn{2}{|r|}{ Continuous Improvement } \\
\hline Plan & $\begin{array}{l}\text { - Objective: To display the sum of } 5 \text { integers } \\
\text { - Identify and declare: } \\
\text { - Input:i1,i2,i3, i4, i5 } \\
\text { - Process: + } \\
\text { - Output: sum }\end{array}$ \\
\hline Do & 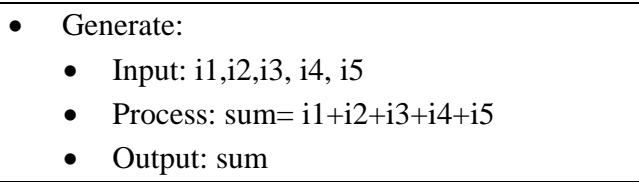 \\
\hline $\begin{array}{c}\text { Chec } \\
\mathbf{k}\end{array}$ & $\begin{array}{l}\text { - } \text { Testing and Debugging } \\
\text { - Output } \\
\text { - Objectives }\end{array}$ \\
\hline $\begin{array}{c}\text { Actio } \\
\text { n }\end{array}$ & $\begin{array}{l}\text { - Display: } \\
\text { - Output: sum }\end{array}$ \\
\hline
\end{tabular}

The proposed framework was designed in accordance with the ARCS motivation model as much as possible so that the students would be adequately motivated. In this paper, the motivation levels of the students were measured using the SIEM assessment standard. Although, and the relation between the proposed framework and motivation were derived from the results of the measurements.

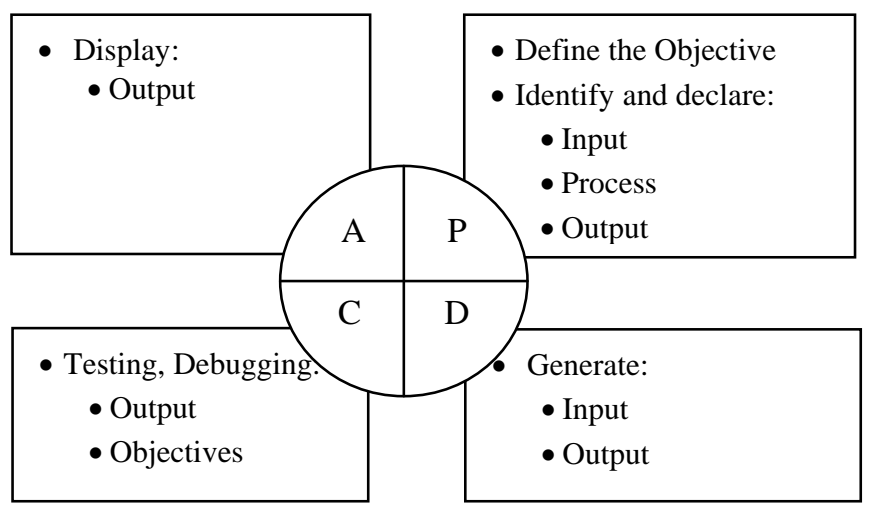

Fig. 2. Problem solving for learning programming

From the problem given, students need to clear up with the suitable plans that need to do, do that plan, check and action for the plan that identified. Figure 2 above show the process need to identify for each programming problem.

\section{B. Pbl In Learning Programming}

PBL (Problem-Based Learning) is a total approach which involves a constructivist approach to learning. According to [43], PBL consists of carefully designed problems which could help to change the teacher-centered philosophy of education to student-centered. PBL has been widely used in Australia, Denmark and China, in variety disciplines such as chemical engineering, electrical engineering, medical, business and entrepreneurs [44].

Learning programming using $\mathrm{PBL}$ is believed able to improve students' learning interest. Through PBL, problems given can be challenging and real, thus novice will motivated to learn. According to [45], PBL tend to enhanced learning interest, improves tutors' professional skill, improve class period and self-learning and teamwork ability among novice.

This paper is proposed to combine the PBL into programming learning by separating the solution of the problems given using Plan-Do-Check-Action phase through e-learning to novice user. According to [34], if everyone within the system follows the PDCA cycle, improvements to the education and the teaching and learning systems will be more effective.

The implementation of PDCA cycles in learning programming can be shown using problem and table 2 below:

Problem : Write a program to input 5 integers, sum them up and output the sum.

Based on the problem given, student need to classify the solution using four continuous improvement steps, PDCA. Though PDCA, novice will have to identify all important things from the problem given including the objective of the solution, input, process and output on Plan phase; generate the process on Do phase; testing and debugging on Check phase; and lastly display the output on Action phase.

\section{CONCLUSION AND FUTURE WORK}

Computer programming has been usually introduced using programming languages that are difficult to understand. From this study, the strategies of previous programming learning methods are identified. This paper began with literature review on learning programming, TQM and motivation. It then continues with materials and methods used, learning programming using TQM and end with the conclusion and future work. As the PDCA model suggests, once the actions are planned, they are carried out, checked and actions taken based on the results. The PDCA cycle is continued until the problem is sufficiently solved.

The results of this paper show the proposed framework in learning programming using TQM. People can take advantages of applying Plan Do Check Action cycles in their application. Preliminary studies should be conducted to identify each activity in PDCA cycle briefly and how can these be transform into the software development. In this research, student will be given with pre-test and post-test using PDCA activities to compare the results.

This paper contributed on the motivations of applying TQM to the programming learning using Problem-based learning through web-based environment. Therefore, we believe that constructive development through PBL and web-based programming learning tends to support cognitive development among novice. The framework aims to provide a robust environment for learning programming by designed an independent platform. These hopefully will helps to decrease the distance between the student and teacher. The methodology relating to the implementation of web-based learning for learning programming, aims to ensure high and constant quality of the teaching process.

\section{ACKNOWLEDGMENT}

We would like to extend sincere appreciation to TATI 
University College and to all members of IT Education Research Group at Computer Science Department, University Malaysia Terengganu, for all the supports and encouragement.

\section{REFERENCES}

[1] W. E. Deming, Out of the Crisis, Massachusetts Institute of Technology, Cambridge, MA., 1986.

[2] M. B. S. H. B. Dale, B. M. Carol, and H. B.Glen, Total Quality Management. 3rd Edition International Edition, Pearson, Prenti.

[3] P. Abdul and R. S. P. Engr, Continous Improvement of Higher Education Quality, 2008, pp. 286-297 2003.

[4] N. Vivekananthamoorthy and S. Sankar, "New Paradigms for Innovation in Teaching and Learning Process," Business, 2009.

[5] B. Kaucic and T. Asic, Improving Introductory Programming with Scratch?, pp. 1095-1100, 2011.

[6] J. H. Greyling, C. B. Cilliers, and A. P. Calitz, "B \#: The Development and Assessment of an Iconic Programming Tool for Novice Programmers," Current, 2006.

[7] S. L. Salcedo and A. M. O. Idrobo, "New tools and methodologies for programming languages learning using the scribbler robot and Alice," presented at 2011 Frontiers in Education Conference (FIE), pp. F4G-1-F4G-6, Oct. 2011.

[8] A. Santos, A. Gomes, and A. J. Mendes, "Integrating New Technologies and Existing Tools to Promote Programming Learning," Algorithms, vol. 3, no. 2, pp. 183-196, Apr. 2010.

[9] J. Ramasamy, S. Valloo, J. Malathy, and P. Nadan, "Effectiveness of Blog for Programming Course in Supporting Engineering Students," Evolution, pp. 1347-1350, 2010.

[10] R. Dvir, E. C. I. Telecom, H. St, and P. Tikva, A TQM Approach to the Improvement of Information Quality Table A: User perceptions of information quality A TQM framework to Information Quality Improvement.

[11] K. Ooi, B. Lin, B. Tan, A. Y. Chong, and M. Inoki, "Software Product Line Evolution Method Based on Kaizen Approach," Knowledge Creation Diffusion Utilization, vol. 6, November 2009, pp. 410-419, 2007.

[12] M. Inoki, "Software Product Line Evolution Method Based on Kaizen Approach," Knowledge Creation Diffusion Utilization, pp. 1207-1214, 2007.

[13] G. L. Jing Feng, Zhiyu CHen, "PDCA Process Application in the Continuous Improvement of Software Quality," presented at Conference, International Engineering, Electronic, 2010, pp. 61-65.

[14] L. X. Wang and M. S. Li, "An active measurement model for software process control and improvement," Journal of Software, Institute of Software Chinese Academy of Sciences, Beijing, pp. 407-41, 2005.

[15] D. K. M. J. C. Turner and P. K. Thorpe, "Students' reports of motivation and negative affect: A theoretical and empirical analysis," Journal of Educational Psychology, vol. 90, pp. 758-771, 1998.

[16] T. G. R. Pekrun and W. Titz, "Academic Emotions in Students' Self-Regulated Learning and Achievement: A Program of Qualitative and Quantitative Research," Educational Psychologist, 2002, pp. 37 no. 2, pp. 91-105.

[17] Y. Takemura, H. Nagumo, K.-L. Huang, and K. Matsumoto, "Analysis of the Relation between the Teaching Materials and Motivation in Programming Education," presented at 20th Conference on Software Engineering Education \& Training (CSEET'07), pp. 317-326, Jul. 2007.

[18] K. M. Y. Law, V. C. S. Lee, and Y. T. Yu, "Learning motivation in e-learning facilitated computer programming courses," Computers \& Education, vol. 55, no. 1, pp. 218-228, Aug. 2010.

[19] A. Pears, S. Seidman, L. Malmi, L. Mannila, E. Adams, J. M. Uni, J. Bennedsen, I. T. U. West, M. Devlin, and J. Paterson, "A Survey of Literature on the Teaching of Introductory Programming," Computer, 2010.

[20] A. I. Wang and B. Wu, "An Application of a Game Development Framework in Higher Education," International Journal of Computer Games Technology, 2009, pp. 1-12, 2009.

[21] L. Vieira, G. Balbinotti, A. Varasquin, and L. Gontijo, "Ergonomics and Kaizen as strategies for competitiveness $\square$ : a theoretical and practical in an automotive industry," Work, vol. 41, pp. 1756-1762, 2012.

[22] P. Reengineering and J. Lyu, "Applying Kaizen and Automation to Process Reengineering," Journal of Manufacturing Systems, vol. 15, no. 2 , pp. $125-132,1996$.
[23] B. Junker, "Kaizen for improvement of rapid protein production for early reagent protein quantities," Biochemical Engineering Journal, vol. 49, no. 3, pp. 435-444, 2010.

[24] M. F. S. Barraza and T. Smith, "Lean-kaizen public service $\square$ : an empirical approach in Spanish local governments," Quality, vol. 21, no. 2, pp. 143-167, 2009.

[25] M. F. Sua and J. Ramis-pujol, "Implementation of Lean-Kaizen in the human resource service process A case study in a Mexican public service," Journal of Manufacturing Technology Management, 2009.

[26] M. R. LI Jingsong, Z. Xiaoguang, and Z. Tianshu, "Medical Process Management by Applying PDCA to EMR," vol. 978-1-4244, 2010.

[27] Q.-L. Du, S.-M. Cao, L.-L. Ba, and J.-M. Cheng, "Application of PDCA Cycle in the Performance Management System," presented at 2008 4th International Conference on Wireless Communications, Networking and Mobile Computing, pp. 1-4, Oct. 2008.

[28] W.-N. Zhang, "The PDCA-based software testing improvement framework," presented at the 2010 International Conference on Apperceiving Computing and Intelligence Analysis Proceeding, pp. 490-494, Dec. 2010

[29] T. A. Walasek and Z. Kucharczyk, "Assuring quality of an e-learning project through the PDCA approach," vol. 48, no. 1, pp. 56-61, 2011.

[30] A. P. Chaves, G. C. L. Leal, and E. H. Moriya Huzita, "An Experimental Study of the FIB Framework Driven by the PDCA Cycle," presented at 2008 International Conference of the Chilean Computer Science Society, pp. 23-31, Nov. 2008.

[31] D. B. Gordon, S. M. Rees, M. R. McCausland, T. a Pellino, S Sanford-Ring, J. Smith-Helmenstine, and D. M. Danis, "Improving reassessment and documentation of pain management.," Joint Commission journal on quality and patient safety / Joint Commission Resources, vol. 34, no. 9, pp. 509-17, Sep. 2008.

[32] R. Raifsnider and D. Kurt, "Lean Six Sigma in higher education $\square$ : Applying proven methodologies to improve quality, remove waste, and quantify opportunities in colleges and universities.," Finance. 2004.

[33] G. Wood and P. Petocz, "One in a Million $\square$ : An Alternative Transformation of the First-Year Statistics Course," Asian SOcial Science, vol. 4, no.3, pp. 43-47, 2008.

[34] H. M. Jani, "Intellectual Capacity Building in Higher Education $\square$ : Quality Assurance and Management," presented at 5th International Conference on New Trends, 2011, pp. 361-366.

[35] D. Lucanin and I. Fabek, "A Visual Programming Language for Drawing and Executing Flowcharts," Architecture, pp. 1679-1684, 2011.

[36] S. Garner, "Learning to Program from Scratch," presented at 2009 9th IEEE International Conference on Advanced Learning Technologies, pp. 451-452, Jul. 2009.

[37] C. F. Panadero, J. V. Román, and C. D. Kloos, "Impact of Learning Experiences Using LEGO Mindstorms ${ }^{\circledR}$ in Engineering Courses," Engineering Education, pp. 503-512, 2010.

[38] K.-W. Han, E. Lee, and Y. Lee, "The Impact of a Peer-Learning Agent Based on Pair Programming in a Programming Course," IEEE Transactions on Education, vol. 53, no. 2, pp. 318-327, May 2010.

[39] W. Dou and W. He, "Compatibility and Requirements Analysis of Distributed Pair Programming," in Proc. of 2010 Second International Workshop on Education Technology and Computer Science, pp. $467-470,2010$

[40] I. Miliszewska and G. Tan, "Befriending Computer Programming $\square$ : A Proposed Approach to Teaching Introductory Programming Difficulties Encountered by First Year Programming Students Impact of Failure / Poor Performance on Students," Issues in Informing Science and Information Technology, vol. 4, 2007.

[41] W. J. Zimmerman, "Kaizen: the search for quality," The Journal of Continuing Higher Education, vol. 39, pp. 7-10, 1991.

[42] K. Ooi, B. Lin, B. Tan, and A. Y. Chong, "Are TQM practices supporting customer satisfaction and service quality?," Journal of Services Marketing, vol. 6, pp. 410-419, November 2011.

[43] Y. Wang, "A case study of Problem-Based Learning instruction design under web-based environment," presented at 2010 2nd International Conference on Education Technology and Computer, pp. V1-586-V1-591, Jun. 2010.

[44] A. Masek and Y. Sulaiman, "Problem Based Learning: A review of the monitoring and assessment model," presented at 2nd International Congress on Engineering Education, December 8-9, 2010, Kuala Lumpur, Malaysia, 2010, pp. 171-175.

[45] M. Xia, Y. Huang, C. Liu, and R. Chai, "Problem-Based Learning of Cardiovascular Physiology in Basic Medical Curriculums," presented at 2010 Second International Workshop on Education Technology and Computer Science, pp. 678-680, 2010. 


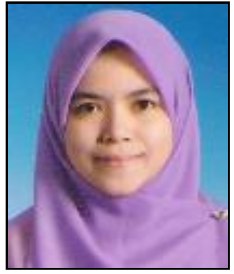

A. Yacob is a lecturer and a researcher at Terengganu Advanced Technical Institute University College (TATiUC). She holds a Master of Science (Information Technology - Manufacturing) and a Bachelor of Science (Computer) at University Technology Malaysia (UTM). Her research interests include Computer programming, Quality control, education and computer industry. Her main research into the learning process.

concentrates on adapting manufacturing techniques

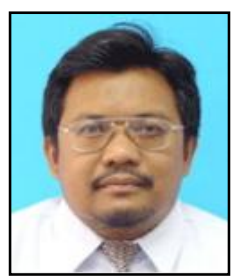

M. H. Yusoff is a lecturer and researcher at Department of Computer Science, UMT. He earned a Ph.D. in Computing Science from the Newcastle University, UK in 2011. He has worked for several years in the areas of e-learning system development and currently working on knowledge management system.

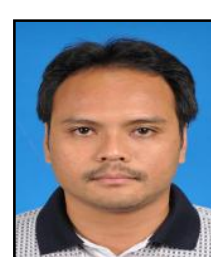

M. Y. Mohd Saman is a Professor at the Departmen of Computer Science, Universiti Malaysia Terengganu (UMT). He was the Deputy Dean (Academics), between 2002 and 2006 at the same university. He received his MSc in Computer Science at Universiti Teknologi Malaysia, and Ph.D in Computer Science (Parallel \& Distribution Processing) at Loughborough University of Technology, Loughborough, England. His main research areas are in the fields of parallel \& distributed computing (MPI) and network performance modelling. He has published more than 90 national and international journal papers and proceedings. 